\title{
Anti-dengue drug: viral polyprotein, a potential target
}

\author{
This article was published in the following Dove Press journal: \\ Drug Design, Development and Therapy \\ 24 June 2016 \\ Number of times this article has been viewed
}

\section{Syed Uzair Mahmood \\ Maryam Mushtaq \\ Maryam Jamil Syed}

Sindh Medical College, Jinnah Sindh

Medical University, Karachi, Pakistan

Correspondence: Syed Uzair Mahmood 43-8-D, Block 6, PECHS, Karachi 75400, Pakistan

Tel +9233 I846 I557

Email uzair.hbb@gmail.com

\section{Dear editor}

We would like to add our views regarding the article "Identification of covalent active site inhibitors of dengue virus protease" by Koh-Stenta et al. ${ }^{1}$ The article suggests the development of a possible drug to combat dengue virus. The drug will inhibit the ability of the virus to replicate by inhibiting the protease enzyme of the virus.

The genome of dengue virus is a single-stranded, positive-sense RNA that encodes for a polyprotein. The polyprotein is translated into three structural components, namely capsid, envelope, and membrane, and seven nonstructural proteins, namely NS1, NS2A, NS2B, NS3, NS4A, NS4B, and NS5. NS3 is a serine protease that has a critical role alongside host cell proteases in the protein breakdown of viral polyprotein that leads to replication. ${ }^{2}$ The foundation of Koh-Stenta et al's study was fundamentally based on the similarity of the amino acid sequence of proteases, especially at the active sites, of the dengue virus and the West Nile virus. ${ }^{3}$ As extensive knowledge was available on the West Nile virus and peptide-bound X-ray crystal structure confirmed many protein-ligand interactions similar to the two viruses, ${ }^{4}$ the knowledge could be applied on dengue virus.

The results of Koh-Stenta et al's research are highly encouraging and show a possibility for the development of an anti-dengue drug in the near future. Another recent study by Dutch investigators suggested that a protein manufactured by the dengue virus NS4B would make a plausible target for antiviral drug. ${ }^{5}$ Their data suggested that a metabolite of acetaminophen (a common pain killer) AM404 was able to inhibit dengue virus replication. In our opinion, this is a ground-breaking discovery, and the study not only brings us one step closer to the development of an antiviral drug against dengue virus, but also enables the determination of when the replication of the virus is inhibited. The latter was achieved by using a derivative of dengue virus that expressed luciferase, a molecule that produces bioluminescence, during replication.

Hence, by correlating the two studies, we conclude that two proteins, ie, NS4B and NS2B, are potential targets for the development of an anti-dengue drug. Moreover, other areas should be explored, of the viral genome, to target other potential sites for drug development. It could be possible to manufacture drugs that stop the virus from entering the cell (entry inhibitors) or drugs that inhibit the strand of RNA ( $5^{\prime}$ capping) inhibiting viral replication. ${ }^{6}$

\section{Disclosure}

The authors report no conflicts of interest in this communication. 


\section{References}

1. Koh-Stenta X, Joy J, Wang SF, et al. Identification of covalent active site inhibitors of dengue virus protease. Drug Des Devel Ther. 2015;9: 6389-6399.

2. Lim SP, Wang QY, Noble CG, et al. Ten years of dengue drug discovery: progress and prospects. Antiviral Res. 2013;100(2):500-519.

3. Erbel P, Schiering N, D'Arcy A, et al. Structural basis for the activation of flaviviral NS3 proteases from dengue and West Nile virus. Nat Struct Mol Biol. 2006;13(4):372-373.
4. van Cleef KW, Overheul GJ, Thomassen MC, Marjakangas JM, van Rij RP. Escape mutations in NS4B render dengue virus insensitive to the antiviral activity of the paracetamol metabolite AM404. Antimicrob Agents Chemother. 2016;60(4):2554-2557.

5. Noble CG, Seh CC, Chao AT, Shi PY. Ligand-bound structures of the dengue virus protease reveal the active conformation. $J$ Virol. 2012;86(1): 438-446.

6. Sampath A, Padmanabhan R. Molecular targets for flavivirus drug discovery. Antiviral Res. 2009;81(1):6-15.

Dove Medical Press encourages responsible, free and frank academic debate. The content of the Drug Design, Development and Therapy 'letters to the editor' section does not necessarily represent the views of Dove Medical Press, its officers, agents, employees, related entities or the Drug Design, Development and Therapy editors. While all reasonable steps have been taken to confirm the content of each letter, Dove Medical Press accepts no liability in respect of the content of any letter, nor is it responsible for the content and accuracy of any letter to the editor.

\section{Publish your work in this journal}

Drug Design, Development and Therapy is an international, peerreviewed open-access journal that spans the spectrum of drug design and development through to clinical applications. Clinical outcomes, patient safety, and programs for the development and effective, safe, and sustained use of medicines are a feature of the journal, which has also been accepted for indexing on PubMed Central. The manuscript management system is completely online and includes a very quick and fair peer-review system, which is all easy to use. Visit http://www.dovepress.com/testimonials.php to read real quotes from published authors.

Submit your manuscript here: http://www.dovepress.com/drug-design-development-and-therapy-journal 